\title{
GRANULOMATOUS INFLAMMATIONS \\ IN THE INTESTINE OF PELOPHYLAX RIDIBUNDUS (ANURA: RANIDAE) CAUSED BY BRANDESIA TURGIDA (PLATHELMINTHES: DIGENEA)
}

\author{
Alexander A. Vedernikov 1,*, Anton O. Svinin'1, Oleg A. Ermakov ${ }^{2, * *}$, \\ Yulia A. Chelyadnikova ${ }^{1}$, Grigoriy A. Musatov ${ }^{1}$, Galina P. Drobot ${ }^{1}$ \\ ${ }^{1}$ Mari State University, Russia \\ *e-mail: aa.vedernikov90@gmail.com \\ ${ }^{2}$ Penza State University, Russia \\ **e-mail:oaermakov@list.ru
}

Received: 30.03.2020. Revised: 11.05.2020. Accepted: 15.05.2020.

\begin{abstract}
The report provides data on granulomatous inflammation in the small intestine of Pelophylax ridibundus, observed in exophytic outgrowths (diverticulums) of duodenum and caused by Brandesia turgida. Amphibians were collected from Protected Areas (Privolzhskaya Lesostep' State Nature Reserve, Penza region, and Sosnovaya Roscha Forest Park near the town Yoshkar-Ola) during the field seasons of 2011-2018. An histological examination was made according to standard histological procedures; we used hematoxylin and eosin stain. The trematode Brandesia turgida was found not only in the Lieberkühn glands, but also in the serosa. Noncaseating epithelioid granulomas were localised in the serosa. Macrophages and single multinuclear PirogovLanghans giant cells were also detected in the serosa. Granular decay, puckering of nuclei and nuclear detritus were detected. Marked leukocyte infiltration with a significant predominance of eosinophils was observed. The periphery of such granulomas can be characterised by a lymphohistiocytic profile. Mycobacterial infection was not detected. The obtained data describe a new case of granulomatous inflammation in amphibians.
\end{abstract}

Key words: 28S rRNA, histopathology, host-parasite interactions, morphology, trematode invasion

\section{Introduction}

A long-term exposure to helminths can lead to disruptions of normal function and morphology of different organs and organ systems of the host (Balls, 1962; Machicado et al., 2016; Zimmermann, 2017). Infestation of parasites into host organism gives rise to a complex response of the immune system that can be species-specific and vary individually (Varyani et al., 2017). Many studies have demonstrated that parasitic influence on host is species-specific too, and include effects on host bodies via various mechanical and chemical factors (Poulin, 1999; Padrós et al., 2018). It can be direct host manipulation or indirect influence of parasite movements or waste products. The interaction of these factors (species-specificity and individuality with the type of parasite exposure) often play a key role in the understanding of the parasite-host relationship, especially for species that have public health, veterinary, and wildlife disease importance (Poulin, 1999; Lafferty \& Kuris, 2012).

Granulematous inflammation can be caused by direct and indirect effects of parasites and pathogens on organisms of their hosts. It is shown that cases of granulomatous inflammation in vertebrates can be caused by mycobacterial infection (Balls, 1962; Crawshaw \& Weinkle, 2000; Soldati et al., 2004; Trott et al., 2004; Mukhopadhyay \& Gal, 2010), trematodes (Gordon et al., 1998; Yepes et al., 2015; Schwartz \& Fallon, 2018), and nematodes (Flieder \& Moran, 1999).

Previously, numerous foci of granulomatous inflammation in the small intestine of Pelophylax ridibundus (Pallas, 1771) were found (Vedernikov et al., 2018). These granulomatous inflammations were associated with exophytic neoplasms of unknown etiology. Here, we describe the origins of granulomatous inflammation and the histopathological picture of intestine wall of $P$. ridibundus and associate it with the invasion of the trematode Brandesia turgida (Brandes, 1888), a widespread intestinal parasite of amphibians.

\section{Material and Methods}

Pelophylax ridibundus individuals were collected during the field seasons of 2011-2018 at 
two localities: (1) Sosnovaya Roscha Forest Park (Yoshkar-Ola, Mari El Republic, Russia), and (2) Ostrovtsovskaya Lesostep' (Privolzhskaya Lesostep' State Nature Reserve, Penza region). A species diagnostics of water frogs from these localities was made by multiplex PCR and DNA flow cytometry (Svinin et al., 2019). Animals were killed with the use of euthanasia (tricaine methanesulfonate, MS222, Sigma). Samples of intestine fragments with exophytic formations were fixed in neutral buffered $10 \%$ formalin, embedded in paraffin using standard procedures. For histological examination, sections were made with a thickness of $5 \mu \mathrm{m}$ on a microtome MC-2. Tissue staining was carried out according to the standard method of hematoxylin and eosin. Because some granulomas can be caused by mycobacterial infections (Balls, 1962), part of the preparations was stained according to ZiehlNeelsen (Leboffe \& Pierce, 2019). Examination of slides was carried out using a Meiji Techno MT4000 microscope.

Molecular identification of trematodes was carried out with adult worms from exophytic formations and fixed in 96\% ethanol. DNA was isolated using the standard salt method with proteinase K (Aljanabi \& Martinez, 1997). We used the 28S rRNA as a diagnostic marker. Amplification was performed using the primers extracted from Tkach et al. (2003). Sequencing was performed on an ABI 3500 automatic sequencer (Applied Biosystems) using standard BigDye ${ }^{\circledR}$ Terminator 3.1 kits and the same primers used for amplification. The sequence was aligned manually in Chromas v. 2.5.1 (Technelysium Ltd.). The identification procedure with the nucleotide sequences known in the GeneBank NCBI was made with use of the BLAST algorithm. The sequence of $28 \mathrm{~S}$ rRNA was deposited in the Genbank base under the number MT260148.

\section{Results and Discussion}

Comparison of the obtained 28S rRNA sequences of the studied trematode species with those available in the Genebank revealed $99.9 \%$ similarity (1247 of $1248 \mathrm{bp}$ ) with the sequence AY220622 from Tkach et al. (2003), which allows identifying studied species as Brandesia turgida.

During anatomical dissection of Pelophylax ridibundus, dense spherical exophytic formations were found, which were most often located on the pyloric part of the stomach and upper part of the duodenum, less often on the jejunum and ileum, isolated cases were found on the large intestine. The formations had the colour of the surrounding tissue, sometimes with dark inclusions on the apical part. Some of them were single outgrowths and had large, up to $7 \mathrm{~mm}$, sizes; group clusters were more often present: 3-4 formations with sizes of $2-3 \mathrm{~mm}$ (Fig. A).
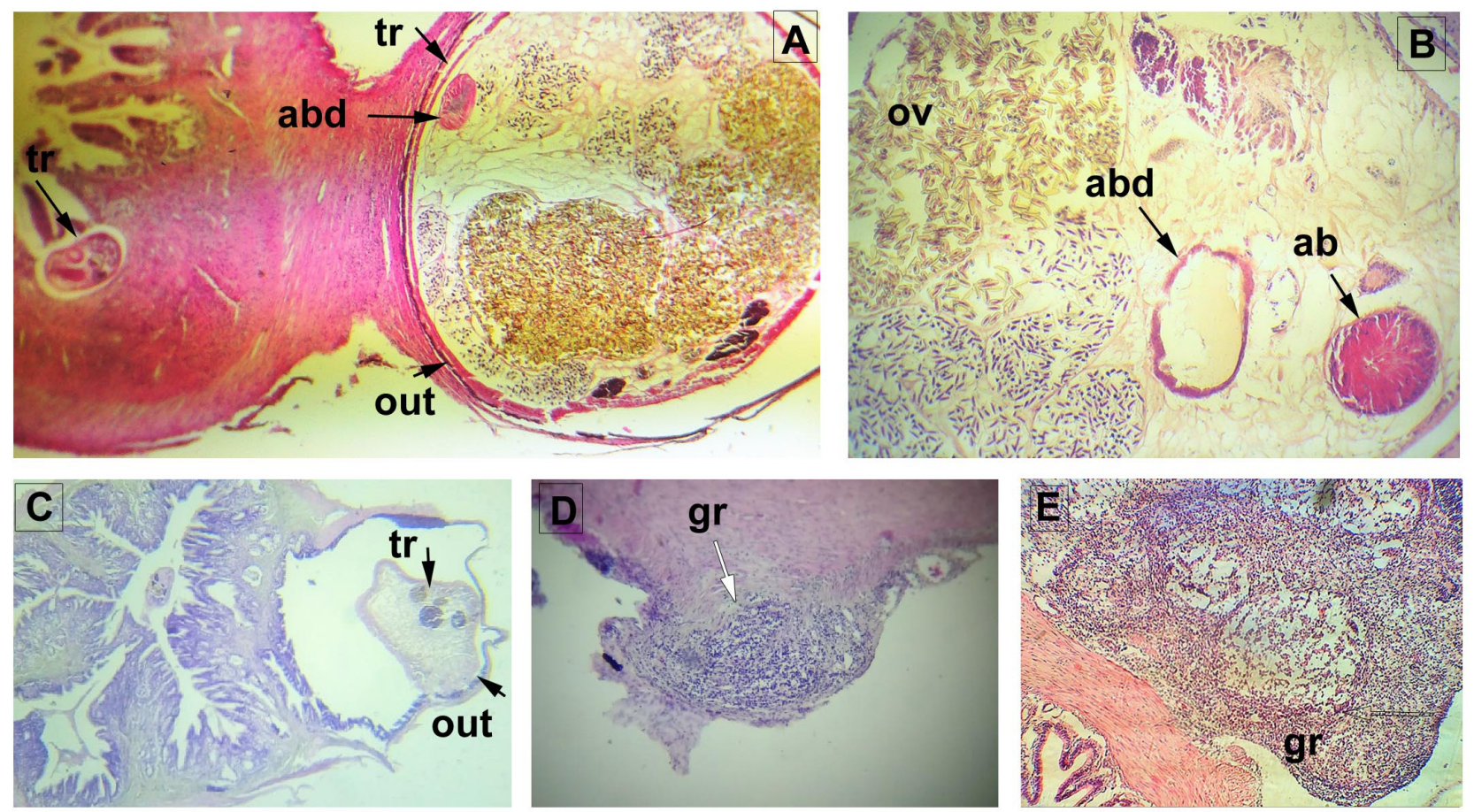

Fig. The histological structure of exophytic neoplasms and the picture of granulomatous inflammation caused by the trematode Brandesia turgida: A, C - appearance of the diverticulum (out) in cross section with the trematode (tr) inside; $\mathrm{B}$ - trematode increase in another section; visible abdominal (abd) and aboral (ab) suckers and ovary with eggs (ov); D, $\mathrm{E}$ - the appearance of some foci of granulomatous inflammation (gr). 
For histological examination, formations together with the surrounding areas of healthy tissue were selected (Fig. A,C). The central part of the exophytic formation is occupied by the body of $B$. turgida with clearly distinguished oral and abdominal suckers and a uterus filled with elongated oval eggs, some of which were not stained with dye (Fig. A,B). Flukes were found in all exophytic formations. In a number of cases, the sections showed a picture of non-caseating epithelioid granulomas localised in serosa (Fig. D,E), in which macrophages and single multinuclear Pirogov-Langhans giant cells were detected. The histological structure of exophytic formation in the intestine is heterogeneous, the cells are located both loosely and quite densely and compactly. Granular decay, puckering of nuclei and nuclear detritus are found in centrally located granuloma cells. Marked leukocyte infiltration with a significant predominance of eosinophils is observed. The periphery of such granulomas is not always clearly distinguishable. Sometimes it is characterised by a lymphohistiocytic profile. To exclude the mycobacterial infection in granulomatous inflammation, the sections were stained according to Ziehl-Neelsen. Mycobacteria were not detected. Among the observed cases, there are formations localised only in the serosa and not affecting other layers of the intestinal wall, however in some cases exophytic formations damaged muscularis externa and mucosa.

The helminth fauna of Pelophylax ridibun$d u s$ is represented by the largest spectrum of species among all amphibian species of the Middle Volga region and totals 36 species of trematodes (Chikhlyaev et al., 2018a). The genus Brandesia is represented in the River Volga basin by one species, B. turgida, which is found in four species of tailless amphibians: Pelophylax ridibundus, P. lessonae (Camerano, 1882), P. esculentus (Linnaeus, 1758), and Rana arvalis Nilsson, 1842 (Kirillov et al., 2012; Chikhlyaev et al., 2018a,b). A characteristic feature of this invasion type is the formation of pocket-like outgrowths (diverticulum) of the small intestine. It has been noted that trematodes live in the highly expanded Lieberkühn glands (Skrjabin, 1948). According to our data, trematodes can indeed occupy crypts of the small intestine. However, they also occur in the underlying layers, including the serosa.

The detected granulomatous inflammation can be the result of a response of Pelophylax ridibundus organism to the waste products of trematodes released into the intestines, or it can develop as an immunological reaction to antigens located on the surface of worms or their eggs. It is known that schistosomes (Schistosoma spp.) can cause granulomatous inflammation that occurs as an immunological reaction to the eggs laid by them that enter the tissues (Zumla \& James, 1996). Antigens on the surface of schistosome eggs (SEA) can stimulate inflammatory and granulomatous reactions in which various populations of immune cells are involved, including T-lymphocytes and granulocytes. In granulomatosis, collagen fibers are deposited and, as a consequence, sclerosis leads to organ damage, and granulomas are observed both in the intestine and in the liver (Rumbley et al., 1998; Yepes et al., 2015; Schwartz \& Fallon, 2018). Trematodes from the Spirorchiidae family caused damage of the cardiovascular system in turtles with endocarditis, arthritis and thrombosis, mainly due to the formation of aneurysms. Granulomas localised in the serosa of the turtle's small intestine and caused by spirochriide eggs (Gordon et al., 1998). The trematode Procerovum varium caused eye granulomas in children in South India (Arya et al., 2016). Granulomatous inflammation can be caused in mammalian lungs by the action of Dirofilaria (Nematoda). A granulomatous reaction is observed in the surrounding tissue, eosinophils are often present, and vasculitis is observed without necrotic processes (Flieder \& Moran, 1999).

Thus, many helminth species can cause local granulomatous inflammation, and some species can induce carcinogenesis (Arora et al., 2019). Our results complement the data on granulomas induced by trematodes and describe a new case for amphibians that needs further study.

\section{References}

Aljanabi S.M., Martinez I. 1997. Universal and rapid saltextraction of high quality genomic DNA for PCR-based techniques. Nucleic Acids Research 25(22): 4692-4693. DOI: 10.1093/nar/25.22.4692

Arora N., Kaur R., Anjum F., Tripathi S., Mishra A., Kumar R., Prasad A. 2019. Neglected Agent Eminent Disease: Linking Human Helminthic Infection, Inflammation, and Malignancy. Frontiers in Cellular and Infection Microbiology 9: 402. DOI: 10.3389/fcimb.2019.00402

Arya L.K., Rathinam S.R., Lalitha P., Kim U.R., Ghatani S., Tandon V. 2016. Trematode Fluke Procerovum varium as Cause of Ocular Inflammation in Children, South India. Emerging Infectious Diseases 22(2): 192-200. DOI: $10.3201 /$ eid2202.150051 
Balls M. 1962. Spontaneous Neoplasms in Amphibia: A Review and Descriptions of Six New Cases. Cancer Research 22(10): 1142-1154.

Chikhlyaev I.V., Kirillova N.Yu., Kirillov A.A. 2018 a. Ecological analysis of trematodes (Trematoda) of marsh frog Pelophylax ridibundus (Ranidae, Anura) from various habitats of the National Park «Samarskaya Luka» (Russia). Nature Conservation Research 3(Suppl.1): 36-50. DOI: 10.24189/ncr.2018.039

Chikhlyaev I.V., Ruchin A.B., Faizulin A.I. 2018b. Short communication: An overview of the trematodes fauna of pool frog Pelophylax lessonae (Camerano, 1882 ) in the Volga Basin, Russia: 1. Adult stages. $\mathrm{Nu}$ santara Bioscience 10(4): 256-262. DOI: 10.13057/ nusbiosci/n100410

Crawshaw G.J., Weinkle T.K. 2000. Clinical and pathological aspects of the amphibian liver. Seminars in Avian and Exotic Pet Medicine 9(3): 165-173. DOI: 10.1053/ax.2000.7133

Flieder D.B., Moran C.A. 1999. Pulmonary dirofilariasis: a clinicopathologic study of 41 lesions in 39 patients. Human Pathology 30(3): 251-256. DOI: 10.1016/ S0046-8177(99)90001-1

Gordon A.N., Kelly W.R., Cribb T.H. 1998. Lesions caused by cardiovascular flukes (Digenea: Spirorchidae) in stranded green turtles (Chelonia mydas). Veterinary Pathology 35(1): 21-30. DOI: 10.1177/030098589803500102

Kirillov A.A., Kirillova N.J., Chikhlyaev I.V. 2012. Trematodes of terrestrial vertebrates in the Middle Volga region. Togliatti: Kassandra. 329 p. [In Russian]

Lafferty K.D., Kuris A.M. 2012. Ecological consequences of manipulative parasites. In: D.P. Hughes, J. Brodeur, F. Thomas (Eds.): Host Manipulation by Parasites. Oxford: Oxford University Press. P. 158-171.

Leboffe M.J., Pierce B.E. 2019. Microbiology: Laboratory Theory \& Application, Essentials. Englewood: Morton Publishing Company. 440 p.

Machicado C., Machicado J.D., Maco V., Terashima A., Marcos L.A. 2016. Association of Fasciola hepatica Infection with Liver Fibrosis, Cirrhosis, and Cancer: A Systematic Review. PLOS Neglected Tropical Disease 10(9): e0004962. DOI: 10.1371/journal.pntd.0004962

Mukhopadhyay M.D., Gal A.A. 2010. Granulomatous lung disease: an approach to the differential diagnosis. $A r$ chives of Pathology and Laboratory Medicine 134(5): 667-690. DOI: 10.1043/1543-2165-134.5.667

Padrós F., Knudsen R., Blasco-Costac I. 2018. Histopathological characterisation of retinal lesions associated to Diplostomum species (Platyhelminthes: Trematoda) infection in polymorphic Arctic charr Salvelinus alpinus. International Journal for Parasitology: Parasites and Wildlife 7(1): 68-74. DOI: 10.1016/j.ijppaw.2018.01.007

Poulin R. 1999. The functional importance of parasites in animal communities: many roles at many levels? International Journal for Parasitology 29(6): 903-914. DOI: 10.1016/S0020-7519(99)00045-4
Rumbley C.A., Zekavat S.A., Sugaya H., Perrin P.J., Ramadan M.A., Phillips S.M. 1998. The schistosome granuloma: characterization of lymphocyte migration, activation, and cytokine production. Journal of Immunology 161(8): 4129-4137.

Schwartz C., Fallon P.G. 2018. Schistosoma "Eggs-Iting” the Host: Granuloma Formation and Egg Excretion. Frontiers in Immunology 9: 2492. DOI: 10.3389/ fimmu.2018.02492

Skrjabin K.I. 1948. Trematodes of Animals and Man: Essentials of Trematodology. Vol. 2. Moscow: Publisher of AS USSR. P. 567-574. [In Russian]

Soldati G., Lu Z.H., Vaughan L., Polkinghorne A., Zimmermann D.R., Huder J.B., Pospischil A. 2004. Detection of Mycobacteria and Chlamydiae in Granulomatous Inflammation of Reptiles: A Retrospective Study. Veterinary Pathology 41(4): 388-397. DOI: 10.1354/vp.41-4-388

Svinin A.O., Bashinskiy I.V., Litvinchuk S.N., Neymark L.A., Osipov V.V., Katsman E.A., Ermakov O.A., Ivanov A.Y., Vedernikov A.A., Drobot G.P., Dubois A. 2019. First record of the Jean Rostand's "anomaly $\mathrm{P}$ " in the marsh frog, Pelophylax ridibundus, in central Russia. Alytes 37(1-2): 31-45.

Tkach V.V., Littlewood D.T.J., Olson P.D., Kinsella J.M., Swiderski Z. 2003. Molecular phylogenetic analysis of the Microphalloidea Ward, 1901 (Trematoda: Digenea). Systematic Parasitology 56(1): 1-15. DOI: 10.1023/A:1025546001611

Trott K.A., Stacy B.A., Lifland B.D., Diggs H.E., Harland R.M., Khokha M.K., Grammer T.C., Parker J.M. 2004. Characterization of a Mycobacterium ulcerans-like infection in a colony of African tropical clawed frogs (Xenopus tropicalis). Comparative Medicine 54(3): 309-317.

Varyani F., Fleming J.O., Maizels R.M. 2017. Helminths in the gastrointestinal tract as modulators of immunity and pathology. American Journal of Physiology: Gastrointestinal and Liver Physiology 312(6): G537-G549. DOI: 10.1152/ajpgi.00024.2017

Vedernikov A.A., Svinin A.O., Drobot G.P. 2018. Granulomatous inflammation of the small intestine in amphibians. In: Biosystems: organisation, behaviour, management. Nizhniy Novgorod. P. 49. [In Russian]

Yepes E., Varela-M R.E., López-Abán J., Rojas-Caraballo J., Muro A., Mollinedo F. 2015. Inhibition of Granulomatous Inflammation and Prophylactic Treatment of Schistosomiasis with a Combination of Edelfosine and Praziquantel. PLOS Neglected Tropical Diseases 9(7): e0003893. DOI: 10.1371/journal.pntd.0003893

Zimmermann A. 2017. Tumor-Like Parasitic Lesions of the Hepatobiliary Tract: Liver Flukes and Other Trematodes. In: A. Zimmermann (Ed.): Tumors and TumorLike Lesions of the Hepatobiliary Tract. Cham: Springer. P. 2399-2416. DOI: 10.1007/978-3-319-26956-6 133

Zumla A., James D.G. 1996. Granulomatous Infections: Etiology and Classification. Clinical Infectious Diseases 23(1): 146-158. DOI: 10.1093/clinids/23.1.146 


\title{
ГРАНУЛЕМАТОЗНОЕ ВОСПАЛЕНИЕ КИШЕЧНИКА PELOPHYLAX RIDIBUNDUS (ANURA: RANIDAE), BЫЗBAHHOE ДЕЙСТВИЕМ ВRANDESIA TURGIDA (PLATHELMINTHES: DIGENEA)
}

\author{
А. А. Ведерников ${ }^{1, *}$, А. О. Свинин ${ }^{1}$, О. А. Ермаков ${ }^{2, * *}$, \\ Ю. А. Челядникова ${ }^{1}$, Г. А. Мусатов ${ }^{1}$, Г. П. Дробот ${ }^{1}$ \\ ${ }^{1}$ Марийский государственный университет, Россия \\ *e-mail: aa.vedernikov90@gmail.com \\ ${ }^{2}$ Пензенский государственный университет, Россия \\ **e-mail:oaermakov@list.ru
}

В сообщении приводятся сведения по гранулематозному воспалению в тонком кишечнике Pelophylax ridibundus, наблюдаемом в экзофитных выростах (дивертикулах) двенадцатиперстной кишки и вызванном действием Brandesia turgida. Амфибии были отловлены на особо охраняемых природных территориях (заповедник «Приволжская лесостепь», Пензенская область, и лесопарк «Сосновая роща»- ООПТ в черте г. Йошкар-Олы) в течение полевых сезонов 2011-2018 гг. Гистологическое исследование было проведено согласно стандартным гистологическим техникам; окрашивание проведено гематоксилином и эозином. Трематода B. turgida отмечена не только в люберкиновых железах, но и в серозной оболочке. Было отмечено наличие неказеозных эпителиоидно-клеточных гранулем, локализованных в серозной оболочке. Там же были обнаружены макрофаги и единичные многоядерные гигантские клетки Пирогова-Ланхганса. Обнаруживается зернистый распад, сморщивание ядер или ядерный детрит. Наблюдается выраженная лейкоцитарная инфильтрация со значительным преобладанием эозинофилов. Периферия таких гранулем может характеризоваться лимфогистиоцитарным профилем. Микобактериальной инфекции не обнаружено. Полученные данные описывают новый случай гранулематозного воспаления у амфибий.

Ключевые слова: 28S pРНК, взаимоотношения «паразит-хозяин», гистопатология, морфология, трематодная инвазия 